\title{
Analisis Pengaruh Kebijakan Moneter, Kebijakan Fiskal, dan Penyaluran Kredit Terhadap Pertumbuhan Ekonomi di Provinsi Jawa Timur Tahun 2006-2016
}

\author{
Muara Nangarumba \\ Dosen Universitas Gajayana Fakultas Ekonomi dan Bisnis dan Staff Tenaga Ahli \\ PPKE Fakultas Ekonomi dan Bisnis, Universitas Brawijaya \\ E-mail: muara07@gmail.com
}

Diterima: 24 Maret 2016; Disetujui: 19 Agustus 2016; Published: 4 November 2016

Permalink/DOI: http://dx.doi.org/10.17977/um002v8i22016p114

\begin{abstract}
Economic growth over the years is believed to be an indicator that can detect how the economics activity in an area. regardless of the debate between development and economic growth, there is no doubt that economic growth remains keep economic role in the region. In keeping with the economic growth in order to remain on a positive trend, the necessary interaction between monetary and fiscal policy. However, both the policy has a different authority. If monetary policy is more controlled by the central government, fiscal policy with fiscal decentralization has two elements of the center and affluent. The interaction between monetary and fiscal policy is believed to give good influence for economic growth, and therefore in this study it was found that through proper credit will be able to have positive influence on economic growth. In addition, this study found the sectors that can be targeted increase in lending growth to the economy, especially the Province of East Java which is the object of research in this study, is expected to increase. These sectors are the Services Sector, Industrial Sector, Agriculture, Trade Sector, and the Construction Sector.
\end{abstract}

Keywords: Economic Growth, OLS Regression, Path Analysis, Fiscal Policy, Monetary Policy, Credit

JEL Classification: E01, E52, E62

\section{PENDAHULUAN}

Meski berada pada periode kontraksi, pertumbuhan ekonomi Jawa Timur selama lima tahun terakhir (2009-2013) menunjukkan kinerja yang relatif baik dimana pada periode tersebut nilai pertumbuhannya selalu berada di atas pertumbuhan ekonomi nasional. Tahun 2012 ekonomi Jawa Timur tumbuh 6,64\%, kemudian melamban menjadi 5,9\% di tahun 2013 dan terus mengalami perlambatan hingga pada Triwulan III-2015 pertumbuhan ekonomi Jawa Timur tumbuh menjadi 5,25\% (c-to-c). Kondisi yang juga terjadi di seluruh dunia ini lebih disebabkan karena pengaruh faktor eksternal, terutama sebagai akibat gejolak perekonomian global yang hingga saat ini belum ada kepastian perbaikannya. Melambannya perekonomian sebagai akibat gejolak perekonomian global ini juga berpengaruh pada kinerja current account yang ditandai dengan 
defisit neraca perdagangan Indonesia yang ditandai pula dengan lesunya pasar ekspor (demand kecil).

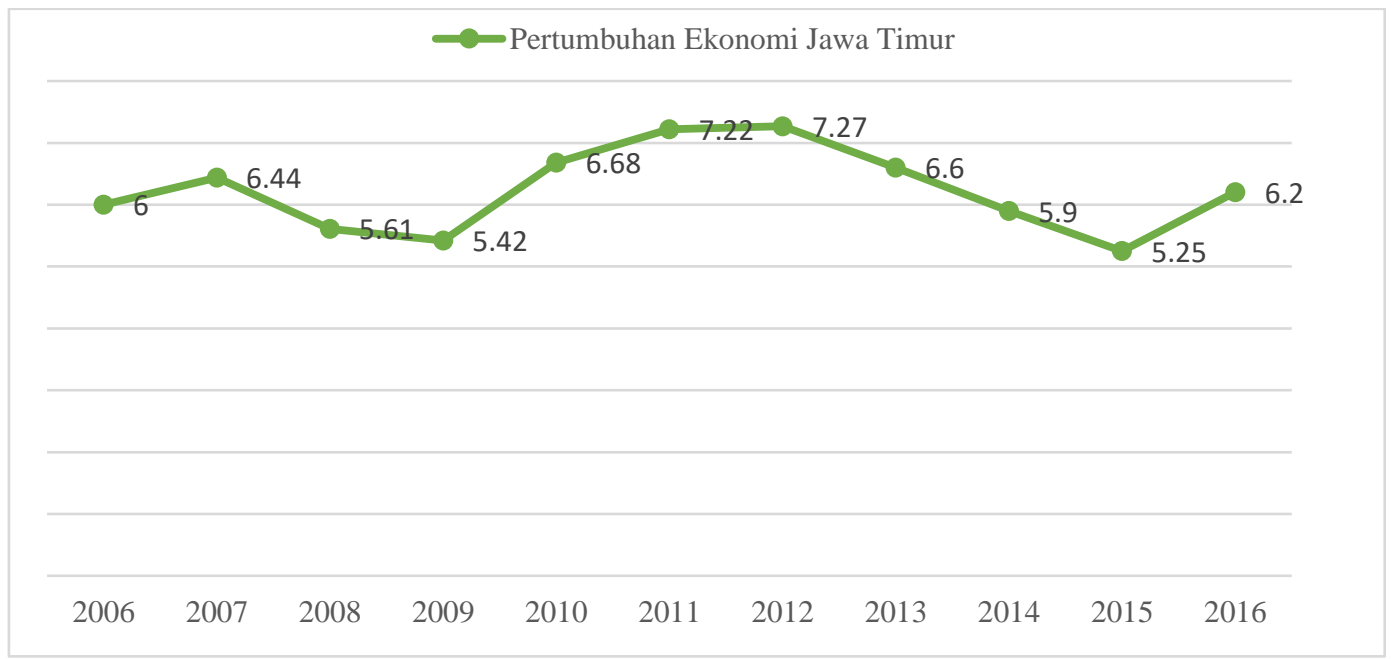

Gambar 1. Pertumbuhan Ekonomi Jawa Timur Tahun 2010-2015.

Sumber: BPS (2016)

Dalam mengatasi hal ini pemerintah pusat melakukan kebijakan dengan cara menurunkan suku bunga tertanggal Januari 2016 sebagaimana dijelaskan gambar berikut ini.

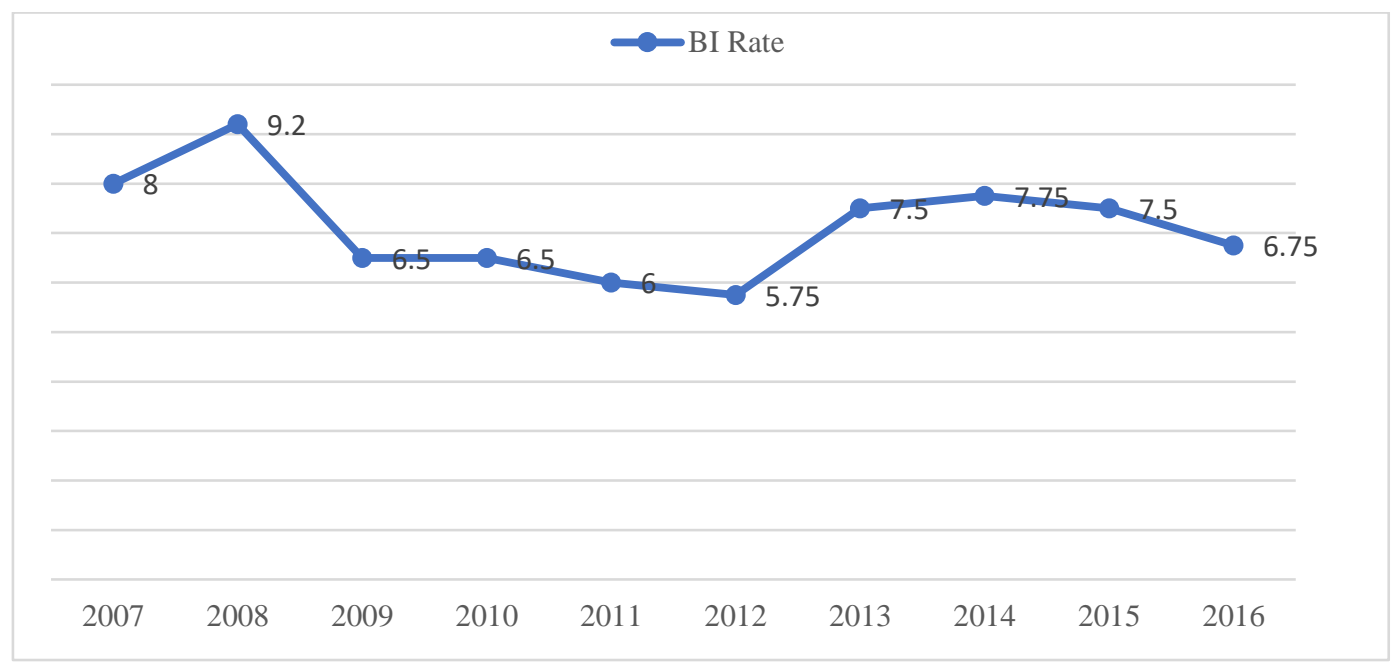

Gambar 2. Trend Suku Bunga Indonesia 2007-2016

Sumber: Bank Indonesia (2016)

Penurunan suku bunga tersebut diharapkan menjadi stimulus terhadap kelesuan ekonomi terutama di Provinsi Jawa Timur. Hal ini dilandasi bahwa hubungan suku bunga dan investasi adalah negatif, dalam artian penurunan suku bunga akan diiringi dengan kenaikan investasi, demikian pula sebaliknya. Dilihat pada awal tahun 2016 pertumbuhan ekonomi melonjak menjadi 6,2 persen. Hal ini merupakan pengaruh dari tumbuhnya perekonomian akibat penurunan suku bunga. Namun dalam rangka menjaga, dan mengupayakan pertubumbuhan ekonomi tetap baik, perlu adanya peran serta pemerintah daerah dalam menjaga 
iklim investasi melalui kebijakan fiskal agar kebijakan tersebut merespon dari adanya kebijakan moneter yang ada.

Secara teoritis maupun empiris, kebijakan moneter dan fiskal mempunyai peranan yang sangat strategis dalam rangka stabilisasi perekonomian, yaitu melalui penyeimbangan permintaan agregat dan penawaran agregat (Rosya dkk, 2013. Apabila perekonomian mengalami tekanan inflasi yang cukup besar, misalnya, maka kebijakan stabilisasi diarahkan pada pengurangan permintaan agregat. Sebaliknya, pada saat ekonomi mengalami resesi maka kebijakan stabilisasi lebih diarahkan untuk menstimulasi permintaan agregat (Fatas \& Mihov, 2012).

Walaupun kebijakan moneter dan fiskal berdampak pada struktur dan kondisi ekonomi yang berlainan, keduanya dapat digunakan secara simultan untuk mencapai dua sasaran stabilitas yang berlainan, misalnya pencapaian keseimbangan internal (stabilitas harga) dan keseimbangan eksternal (neraca pembayaran). Dalam kondisi tersebut, kebijakan moneter dan fiskal dapat dikelola atau dikoordinasikan sedemikian rupa agar stimulus yang dihasilkan oleh kedua kebijakan tersebut dapat diarahkan untuk mempengaruhi perekonomian, dalam artian tidak saling meniadakan atau bahkan menimbulkan pengaruh yang berlebihan, sehingga dapat mendukung pencapaian stabilitas harga dan pencapaian neraca pembayaran yang sehat secara bersama-sama (Goeltom, 2012).

Dalam rangka mencapai hal tersebut penyaluran kredit berperan sebagai perantara, dikarenakan penyaluran kredit merupakan faktor yang dipengaruhi oleh kebijakan moneter dan fiskal (Alatan \& Basana, 2015). Dari tahun 2007 hingga 2016, penyaluran kredit cenderung mengalami kenaikan dari segi jumlah, akan tetapi dari sisi pertumbuhan cenderung berfluktuatif, setelah sempat tinggi pada tahun 2012 pertumbuhan penyaluran kredit turun drastis pada tahun 2013, hal ini diakibatkan kondisi krisis ekonomi global yang melanda, kemudian pada tahun berikutnya pada tahun 2014 terjadi kenaikan namun kembali turun hingga tahun 2016. Dari data ini kita dapat menyimpulkan bahwa dengan pertumbuhan ekonomi yang melambat dan baru saja kembali membaik akibat penurunan suku bunga, penyaluran kredit masih belum mendapat banyak berubah (Idayanti, 2005). Hal ini dikarenakan masyarakat masih menanti kestabilan akan penurunan suku bunga. Akhir-akhir ini bank-bank sedang gencar-gencarnya mempromosikan penurunan suku bunga pinjaman, akan tetapi efek dari hal ini baru dapat dinilai tiga bulan mendatang. Hal ini dikarenakan mosi tidak percaya yang beredar di masyarakat terkait kondisi pemerintahan yang sedang diliputi banyak isu poltik ataupun ekonomi. Terkait strategi menaikkan penyaluran kredit di Jawa Timur, dari sisi kebijakan moneter penurunan suku bunga merupakan langkah baik, dikarenakan penurunan suku bunga akan diiringi dengan naiknya kecenderunga masyarakat untuk melakukan kredit baik untuk konsumsi atau investasi. Terkait kenaikan investasi hal ini merupakan salah satu faktor yang dapat menaikkan pertumbuhan ekonomi. Sehingga diharapkan dalam jangka bulan-bulan ke depan, masyarakat mulai kembali melakukan kredit (Muzakky dkk., 2015).

Selain hal-hal yang bersifat analisis ekonomi, dalam menaikkan penyaluran kredit, perlu dilakukan kemudahan dalam pengajuan kredit, dikarenakan masyarakat tentu akan kurang berminat melakukan pinjaman jika proses dalam pengajuan kredit cukup rumit. Namun sifat dari pemberian kredit yang mampu mengatasi kebutuhan dana masyarakat khususnya kaum pengusaha, menjadikan 
kredit menjadi kebutuhan bagi sebagian kalangan, dan memiliki permintaannya sendiri, meskipun tentunya pada jangka panjang akan menjadi beban yang harus ditanggung para penerima kredit untuk membayar angsuran. Penyaluran kredit memiliki hubungan negatif dengan tingkat suku bunga, dalam artian penurunan suku bunga akan diiringi dengan peningkatan penyaluran kredit.

Tabel 1. Perkembangan Penyaluran Kredit Jawa Timur 2007-2016.

\begin{tabular}{ccc}
\hline Tahun & Penyaluran Kredit & Pertumbuhan (\%) \\
\hline 2007 & 106,371 & \\
\hline 2008 & 133,307 & $25,32 \%$ \\
\hline 2009 & 132,236 & $-0,80 \%$ \\
\hline 2010 & 127,117 & $-3,87 \%$ \\
\hline 2011 & 190,064 & $49,52 \%$ \\
\hline 2012 & 279,965 & $47,30 \%$ \\
\hline 2013 & 307,723 & $9,91 \%$ \\
\hline 2014 & 401,291 & $30,41 \%$ \\
\hline 2015 & 467,608 & $16,53 \%$ \\
\hline 2016 & 542,643 & $16,05 \%$ \\
(proyeksi) & & \\
\hline
\end{tabular}

Sumber: BPS (2016)

Peningkatan penyaluran kredit sendiri biasanya diiringi dengan peningkatan Investasi, dikarenakan penyaluran kredit memiliki dua fungsi alokasi yakni investasi dan konsumsi, kebutuhan masyarakat akan kredit umumnya terkait dengan barang yang memilliki nilai investasi. Sehingga mempertimbangkan halhal diatas, penyaluran kredit dirasa tepat sebagai variabel antara bagi kebijakan moneter dan fiskal. Sehingga, penelitian ini berusaha menyajikan bentuk interkasi kebijakan fiskal terhadap kebijakan moneter dalam hal mempengaruhi pertumbuhan ekonomi agar tetap terjaga. Sehingga dengan pertumbuhan ekonomi yang baik, diharapkan akan memberikan dampak yang positif bagi masyarakat khususnya Provinsi Jawa Timur.

Selain itu tujuan dari penelitian ini adalah menemukan dan memberikan peringkat terhadap penyaluran kredit pada sektor mana saja yang mampu memberikan pengaruh positif terhadap pertumbuhan ekonomi, khususnya Provinsi Jawa Timur. Dengan adanya informasi tersebut maka akan memberikan gambaran akan penyaluran kredit mana yang perlu ditambah agar dapat menaikan pertumbuhan ekonomi Provinsi Jawa Timur.

\section{KAJIAN PUSTAKA}

\section{Kebijakan Moneter dan Fiskal}

Kebijakan moneter adalah tindakan yang dilakukan oleh penguasa moneter (biasanya bank sentral) untuk mempengaruhi jumlah uang beredar dan kredit yang pada gilirannya akan mempengaruhi kegiatan ekonomi masyarakat (Nopirin, 1992). Bank sentral adalah lembaga yang berwenang mengambil langkah kebijakan moneter untuk mempengaruhi jumlah uang beredar. Kebijakan moneter merupakan salah satu bagian integral dari kebijakan ekonomi makro. Kebijakan moneter ditujukan untuk mendukung tercapainya sasaran ekonomi makro, yaitu pertumbuhan ekonomi yang tinggi, stabilitas harga, pemerataan pembangunan, dan keseimbangan neraca pembayaran (Kuncoro, 2004). 
Kebijakan fiskal merupakan salah satu kebijakan ekonomi makro yang otoritas utamanya berada di tangan pemerintah dan diwakili oleh Kementerian Keuangan. Hal tersebut diatur dalam dalam Undang-Undang Nomor 17 Tahun 2003 tentang Keuangan Negara, yang menyebutkan bahwa presiden memberikan kuasa pengelolaan keuangan dan kekayaan negara kepada Menteri Keuangan selaku pengelola fiskal dan wakil pemerintah dalam pemilikan kekayaan negara yang dipisahkan. Kebijakan fiskal umumnya merepresentasikan pilihan-pilihan pemerintah dalam menentukan besarnya jumlah pengeluaran atau belanja dan jumlah pendapatan, yang secara eksplisit digunakan untuk mempengaruhi perekonomian. Berbagai pilihan tersebut, dalam tataran praktisnya dimanifestasikan melalui anggaran pemerintah, yang di Indonesia lebih dikenal dengan Anggaran Pendapatan dan Belanja Negara (APBN).

Kebijakan fiskal adalah kebijakan yang dilakukan oleh pemerintah dalam rangka mendapatkan dana-dana dan kebijaksanaan yang ditempuh oleh pemerintah untuk membelanjakan dananya tersebut dalam rangka melaksanakan pembangunan Atau dengan kata lain, kebijakan fiskal adalah kebijakan pemerintah yang berkaitan dengan penerimaan atau pengeluaran Negara.

\section{Koordinasi Kebijakan Moneter dan Fiskal}

Secara teoritis maupun empiris, kebijakan moneter dan fiskal mempunyai peranan yang sangat strategis dalam rangka stabilisasi perekonomian, yaitu melalui penyeimbangan permintaan agregat dan penawaran agregat. Apabila perekonomian mengalami tekanan inflasi yang cukup besar, misalnya, maka kebijakan stabilisasi diarahkan pada pengurangan permintaan agregat. Sebaliknya, pada saat ekonomi mengalami resesi maka kebijakan stabilisasi lebih diarahkan untuk menstimulasi permintaan agregat.

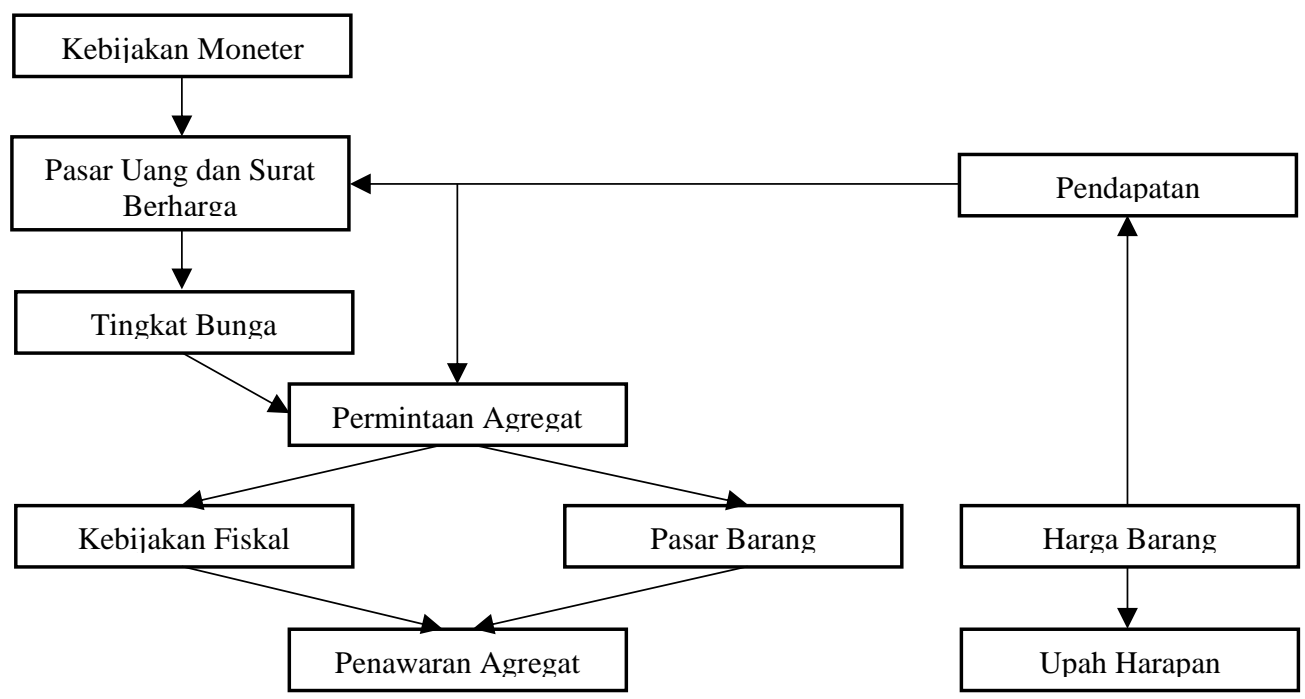

Gambar 3. Hubungan Kebijakan Moneter dan Kebijakan Fiskal.

Sumber: Nanga (diolah), 2005

Walaupun kebijakan moneter dan fiskal berdampak pada struktur dan kondisi ekonomi yang berlainan, keduanya dapat digunakan secara simultan untu mencapai dua sasaran stabilitas yang berlainan, misalnya pencapaian keseimbangan internal (stabilitas harga) dan keseimbangan eksternal (neraca 
pembayaran). Dalam kondisi tersebut, kebijakan moneter dan fiskal dapat dikelola atau dikoordinasikan sedemikian rupa agar stimulus yang dihasilkan oleh kedua kebijakan tersebut dapat diarahkan untuk mempengaruhi perekonomian, dalam artian tidak saling meniadakan atau bahkan menimbulkan pengaruh yang berlebihan, sehingga dapat mendukung pencapaian stabilitas harga dan pencapaian neraca pembayaran yang sehat secara bersama-sama (Goeltom, 2012; Mahdi dkk., 2014).

Pada gambar 3 dijelaskan bahwa kebijakan moneter akan mempengaruhi pasar uang dan pasar surat berharga, pasar uang dan surat berharga tersebut akan menentukan tinggi rendahnya tingkat bunga, sedangkan tingkat bunga akan mempengaruhi permintaan agregat. Kebijakan fiskal akan mempunyai pengaruh terhadap permintaan agregat dan penawaran agregat, di mana permintaan agregat dan penawaran agregat akan menentukan keadaan di pasar barang dan jasa.

\section{Model Mundell-Fleming}

Model Mundell Fleming tidak jauh berbeda dengan model IS-LM. Kedua model ini menekankan interaksi antara pasar barang dan pasar uang. Keduanya juga mengasumsikan bahwa tingkat harga adalah tetap dan menunjukkan apa yang menyebabkan fluktuasi jangka pendek dalam pendapatan agregat (atau, sama dengan pergeseran dalam kurva permintaan agregat). Perbedaaan pentingnya adalah bahwa model IS-LM mengasumsikan perekonomian tertutup, sedangkan dalam model Mundell Fleming mengasumsikan perekonomian terbuka (IS*$\mathrm{LM}^{*}$ ). Model Mundell Fleming membuat suatu asumsi penting dan ekstrem yaitu: model ini mengasumsikan bahwa perekonomian yang sedang dipelajari adalah perekonomian terbuka kecil dengan mobilitas modal sempurna. Artinya, perekonomian bisa meminjam atau memberi pinjaman sebanyak yang ia inginkan di pasar keuangan dunia dan, sebagai akibatnya tingkat bunga perekonomian (r) ditentukan oleh tingkat bunga dunia $\left(\mathrm{r}^{*}\right)$. Secara matematis, kita bisa menulis asumsi ini sebagai

$$
\mathrm{r}=\mathrm{r}^{*}
$$

Tingkat bunga dunia ini diasumsikan tetap secara eksogen karena perekonomian tersebut relatif kecil dibandingkan perekonomian dunia sehingga bisa meminjam atau memberi pinjaman sebanyak yang ia inginkan di pasar keuangan dunia tanpa mempengaruhi tingkat bunga dunia. Tanda asterik pada IS* - LM* menunjukkan bahwa pada model ini menggunakan asumsi tingkat bunga konstan pada tingkat bunga dunia $r^{*}$.

Tingkat bunga dunia ini diasumsikan tetap secara eksogen karenaperekonomian tersebut relatif kecil dibandingkan perekonomian dunia sehingga bisa meminjam atau memberi pinjaman sebanyak yang ia inginkan di pasar keuangan dunia tanpa mempengaruhi tingkat bunga dunia. Tanda asterik pada IS* - LM* menunjukkan bahwa pada model ini menggunakan asumsi tingkat bunga konstan pada tingkat bunga dunia $\mathrm{r}^{*}$.

Dalam perekonomian terbuka kecil, tingkat bunga domestik mungkin naik sedikit selama jangka pendek, tetapi dalam sekejap, pihak asing akan melihat tingkat bunga yang lebih tinggi itu, dan mulai memberi pinjaman ke negara ini (misalnya dengan membeli obligasi negara ini). Aliran modal masuk akan mendorong tingkat bunga domestik kembali menuju r*. Demikian juga jika setiap peristiwa yang terjadi mulai menggerakan tingkat bunga domestik turun ke 
bawah, modal akan mengalir ke luar negara untuk menghasilkan pengembalian yang lebih tinggi, dan aliran ke luar modal ini akan mendorong tingkat bunga domestik kembali naik menuju $\mathrm{r}^{*}$. Jadi, persamaan $\mathrm{r}=\mathrm{r}^{*}$ menunjukan asumsi bahwa aliran modal internasional cukup dan juga memadai untuk mempertahankan tingkat bunga domestik sama dengan tingkat bunga dunia.

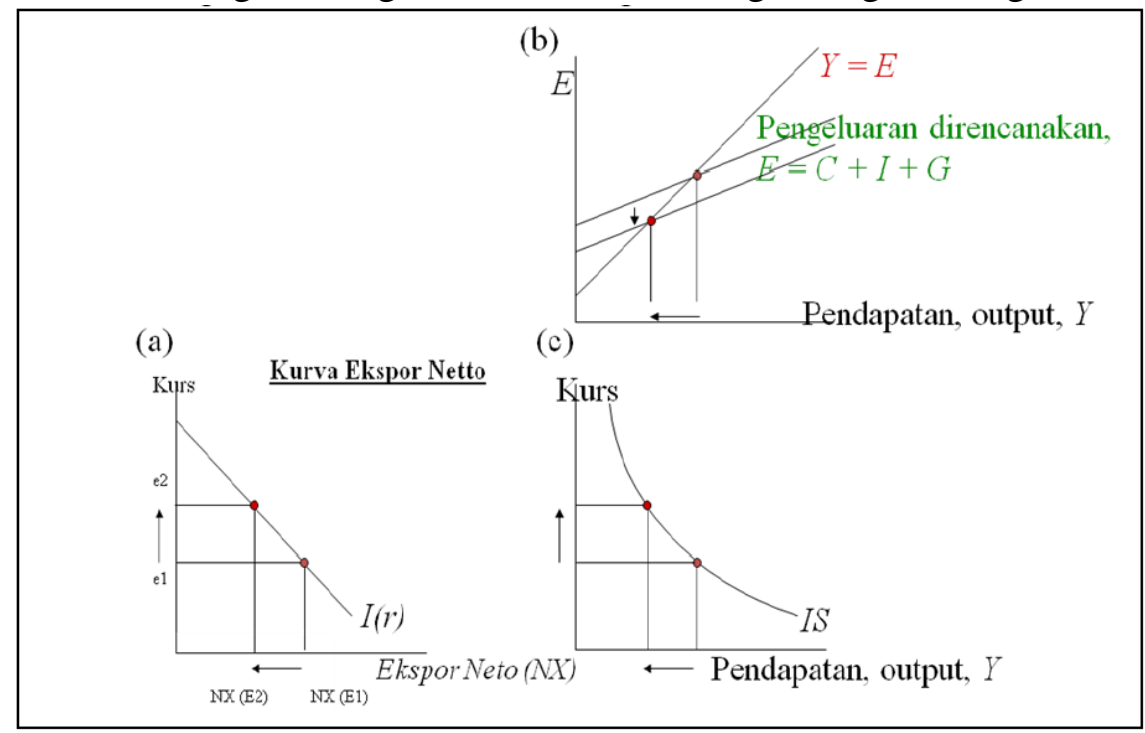

Gambar 4. Pergerakan Kurva IS Mundell- Fleming

Sumber: Mankiw(diolah), 2012

Kurva IS* diderivasi dari kurva ekspor - neto dan perpotongan Keynesian. Dari gambar 4 pada gambar, (a) menunjukan kurva ekspor- neto: kenaikan kurs dari e1 ke e2 mengurangi ekspor-neto dari $\mathrm{NX}(\mathrm{e} 1)$ ke $\mathrm{NX}(\mathrm{e} 2)$. (b) menunjukkan perpotongan Keynesian: penurunan ekspor-neto dari NX(e1) ke NX(e2) menggeser akan kurva pengeluaran yang direncanakan ke bawah dan menurunkan pendapatan dari Y1 ke Y2. (c) menunjukkan kurva IS* yang meringkas hubungan antara kurs dan pendapatan: semakin tinggi kurs, semakin rendah tingkat pendapatan. Kurva IS* diderivasi dari kurva ekspor-neto dan perpotongan Keynesian

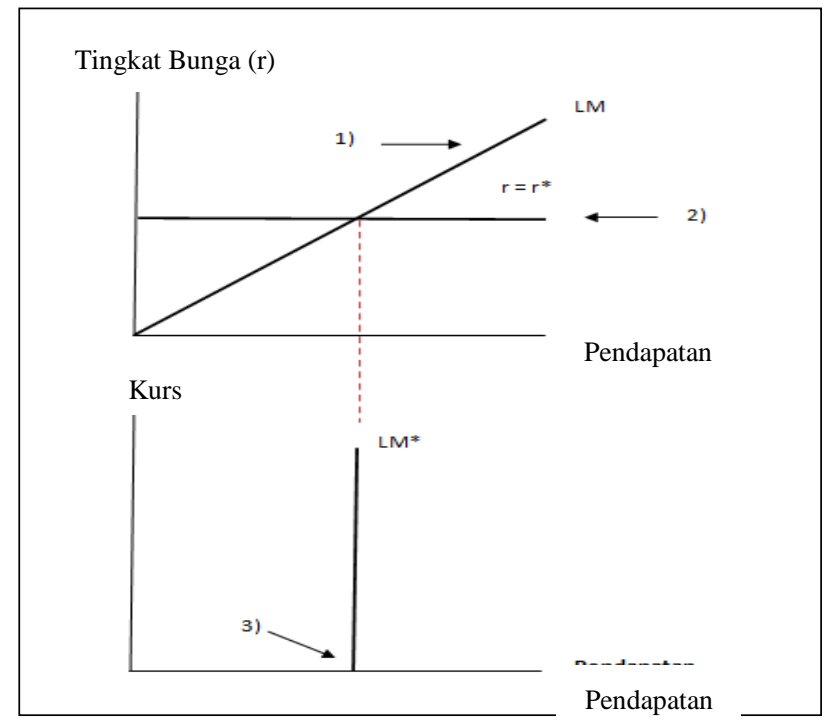

Gambar 5. Pergerakan Kurva LM Mundell- Fleming Sumber: Mankiw (diolah), 2012 


\section{METODE}

Jenis penelitian yang digunakan dalam penelitian ini adalah penelitian deskriptif kuantitatif. Pengertian dari penelitian deskriptif adalah salah satu metode penelitan yang banyak digunakan pada penelitian yang bertujuan untuk menjelaskan suatu kejadian. Penelitian desktiptif adalah sebuah penelitian yang bertujuan untuk memberikan atau menjabarkan suatu keadaan atau fenomena yang terjadi saat ini dengan menggunakan prosedur ilmiah untuk menjawab masalah secara actual (Baltagi, 2001).

Sedangkan, penelitian kuantitatif menurut (Donmoyer, 2008) adalah pendekatan-pendekatan terhadap kajian empiris untuk mengumpulkan, menganalisa, dan menampilkan data dalam bentuk numerik daripada naratif. Penelitian kuantitatif sering dipandang sebagai antitesis atau lawan dari penelitian kualitatif, walau sebenarnya pembedaan kualitatif-kuantitatif tersebut agak menyesatkan. Mereka melakukan kuantifikasi gradasi kualitas menjadi skala-skala numerik yang memungkinkan analisis statistik. Dari kedua pengertian tersebut, penulis beranggapan bahwa metode penelitian deskriptif kuantitatif sesuai dengan penelitian yang dilaksanakan oleh penulis.

\section{Ruang Lingkup, Metode Pengumpulan Data dan Variabel Penelitian}

Lingkup dari penelitian adalah Provinsi Jawa Timur selama 10 tahun terakhir yakni tahun 2006 hingga 2016 (Januari 2016).

\section{Metode Analisis}

Metode Analisis yang digunakan pada penelitian ini menggunakan Analisis Jalur dengan bentuk funngsional model regresi berjenis model log-lin atau lebih dikenal dengan semi log. Analisis regresi dalam statistika adalah salah satu metode untuk menentukan hubungan sebab-akibat antara satu variabel dengan variabel (-variabel) yang lain.

Tabel 3. Perkembangan Penyaluran Kredit Jawa Timur 2007-2016.

\begin{tabular}{ll}
\hline \multicolumn{1}{c}{ Variabel } & \multicolumn{1}{c}{ Sumber } \\
\hline Pertumbuhan Ekonomi & www.bps.go.id \\
\hline Tingkat Suku Bunga & www.bi.go.id \\
\hline Jumlah Belanja Modal & www.bps.go.id \\
\hline Jumlah Penyaluran Kredit & www.bps.go.id \\
\hline
\end{tabular}

Sumber : Data Diolah, 2016

Analisis Jalur merupakan pengembangan regresi terutama terkait pengembangan identifikasi pengembangan hubungan kausal. seberapa istilah dan defenisi dalam analisis jalur. (1) Dalam Analisis Jalur, kita hanya menggunakan sebuah lambung variabel, yaitu $X$. Untuk membedakan $X$ yang satu dengan $X$ yang lainnya, kita menggunakan subscript (indeks). Contoh: X1, X2, X3, ....., Xk. (2) Kita membedakan dua jenis variabel, yaitu variabel variabel yang menjadi pengaruh (exogenous variable), dan variabel yang dipengaruhi (endogenous variable). (3) Lambang hubungan langsung dari eksogen ke endogen adalah panah bermata satu, yang bersifat recursive atau arah hubungan yang tidak berbalik/satu arah. (4) Diagram jalur merupakan diagram atau gambar yang mensyaratkan hubungan terstruktur antar variabel. Selanjutnya, berikut ini adalah sumber data dari variabel yang digunakan pada penelitian ini. 


\section{HASIL DAN PEMBAHASAN}

Pada pembahasan kali ini menerangkan bagaimana analisis jalur dibuat. Dimana sebelumnya data-data tersebut telah lolos uji asumsi klasik terlebh dahulu. Berawal dari diagram jalur sebagai berikut:

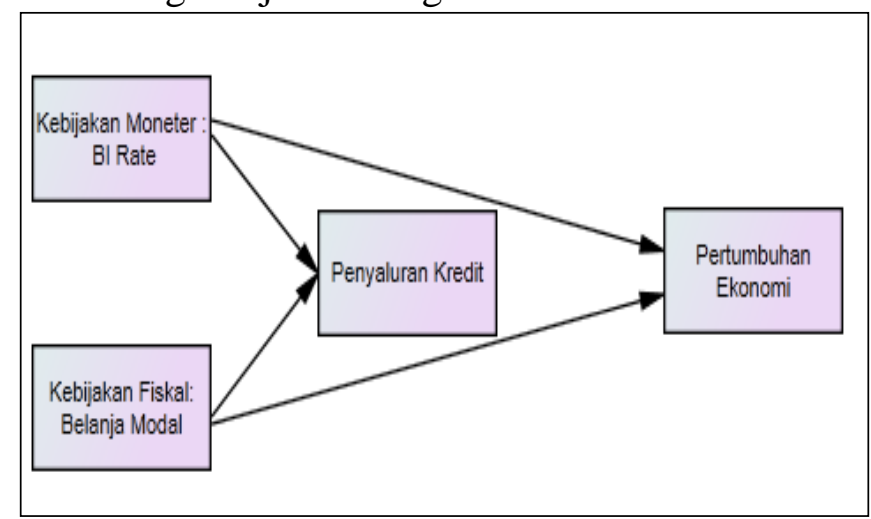

Gambar 6. Diagram Jalur

Sumber: Data Diolah, 2016

Pada gambar ini kita ingin mengetahui pengaruh dari Tingkat Bunga (LNBIRATE) dan Belanja Modal (LNBM) terhadap Pertumbuhan Ekonomi melalui Penyaluran Kredit Tingkat Bunga mewakili dari kebijakan moneter dan belanja modal mewakili kebijakan fiskal yang dapat langsung menyentuh sektor riil. Diharapkan dengan ada sinegrasi antar kedua kebijakan tersebut akan dapat memberikan dampak positif terhadap pertumbuhan ekonomi. Dalam rangka membentuk sinegrasi tersebut, dibutuhkan variabel antara atau penghubung, dimana pada penelitian ini diyakini bahwa variabel tersebut adalah penyaluran kredit.

Dimana dengan mengatur tingkat bunga dan belanja modal yang ada akan dapat mempengaruhi penyaluran kredit. Asumsi yang dibangun pada penelitian ini adalah dimana adanya penurunan tingkat suku bungan dan penambahan belanja modal akan menaikan penyaluran kredit. Artinya masyarakat semakin bergairah untuk mencari kredit untuk mengekspansi usahanya, sehingga diharapkan pertumbuhan ekonomi akan naik. Selanjutnya menggunakan aplikasi Amos 22, skema tersebut dianalisis dengan Goodnes of Fit (kecocokan model sebagai berikut)

Tabel 4. Tabel Goodness of Fit Analisis Jalur.

\begin{tabular}{lccc}
\hline $\begin{array}{c}\text { Goodness of Fit } \\
\text { Indeks }\end{array}$ & Cut of Value & Hasil Analisis & $\begin{array}{c}\text { Evaluasi } \\
\text { Model }\end{array}$ \\
\hline Chi Square & $\begin{array}{c}\text { Nilai Probability Chi-squares }> \\
0,05 \text { menandakan data empiris } \\
\text { identik dengan teori/model } \\
\text { (Ghozali \& Fuad. 2008) }\end{array}$ & 0,82 & Baik \\
& $<2$ & 1,49 & \\
\hline CMIN & $>0,90$ atau Mendekati 1 (Santoso, & 0,836 & Baik \\
\hline GFI & 2015) & \\
\hline
\end{tabular}

Sumber: Data Diolah, 2016

Dengan hasil goodness of fit diatas maka model tersebut memiliki tingkat kepercayaan yang cukup tinggi, terutama dari chi square, yakni model ini 
memiliki tingkat kepercayaan 82 persen. Selanjutnya kita akan membahas mengenai hasil dari analisis jalur dimana kita akan memulainya dari hubungan langsung. Diketahui bahwa terdapat 45 hubungan langsung pada model ini. Yakni, tingkat bunga mempengaruhi jumlah penyaluran kredit, belanja modal mempengaruhi jumlah penyaluran kredit, tingkat bunga mempengaruhi pertumbuhan ekonomi, jumlah penyaluran kredit mempengaruhi pertumbuhan ekonomi dan belanja modal mempengaruhi pertumbuhan ekonomi. Dimana kesuluruhan hubungan antar variabel tersebut signifikan dengan $\mathrm{p}$-value dibawah tingkat alpha sebesar $0,05 \%$.

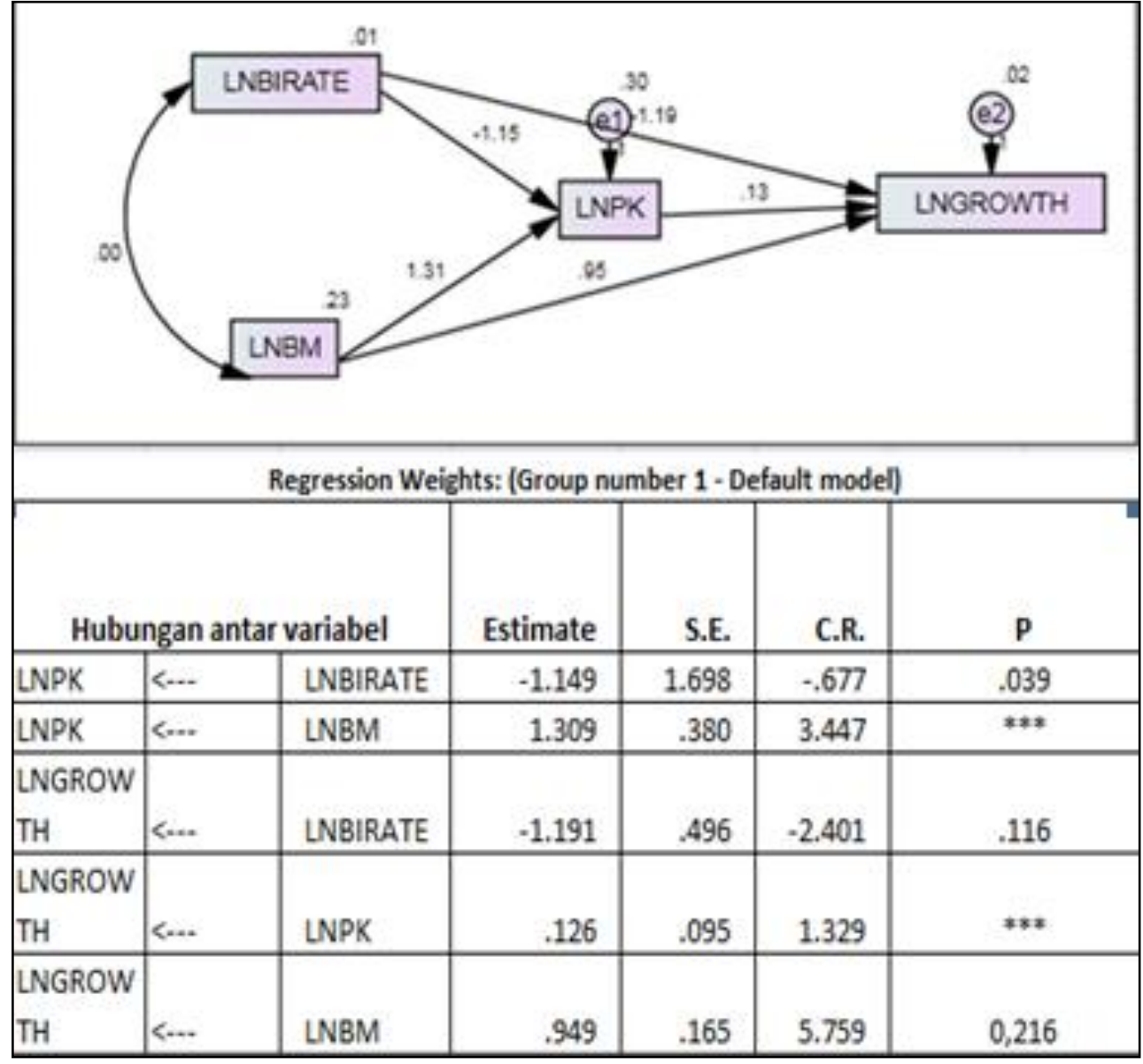

Gambar 7. Hasil Analisis Jalur.

Sumber: Amos 22 (diolah), 2016

Setelah diketahui bahwa model yang dibuat cocok dan memenuhi kelayakan goodness of fit, selanjutnya adalah menjabarkan hubungan langsung yang ada. Pada hasil diatas ternyata terdapat 3 hubungan langsung, dapat dilihat dari perbandingan antara P-value dengan tingkat alpha sebesar 0,05. Penjelasan akan hubungan langsungnya adalah sebagai berikut:

1. Tingkat Suku Bunga Mempengaruhi Jumlah Penyaluran Kredit

Dengan P-Value 0,039 < 0,05 maka hubungan ini memiliki keyakinan 95\% bahwa terdapat hubungan langsung antara Tingkat Suku Bunga dengan Jumlah Penyaluran Kredit, hubungan ini memiliki estimasi sebesar -1,149 dengan adanya pengaruh negatif maka penurunan sebesar 1 persen dari 
tingkat bunga akan menaikkan penyaluran kredit sebesar 1 Triliun Rupiah begitu pula sebaliknya. Hal ini sesuai dengan teori bahwa semakin rendah suku bunga akan menaikkan kecenderunga masyarakat untuk mengajukan kredit, sehingga hal ini akan menaikkan kecenderungan masyarakat untuk melakukan investasi.

2. Jumlah Belanja Modal Mempengaruhi Jumlah Penyaluran Kredit

Dengan P-Value yang signifikan dibawah 0,01 persen $(* * *$ melambangkan bahwa signifikan dibawah 0,01 persen) maka dengan kepercayaan mendekati 99\% dipercayai bahwa Jumlah Belanja Modal memiliki hubungan langsung. Dengan pengaruh positif, maka angka pada estimasi ini menjelaskan bahwa jika terjadi peningkatan pada jumlah belanja modal sebesar 1 Milyar Rupiah akan menaikan jumlah penyaluran kredit sebesar 1,309 Trilun, berlaku pula jika sebaliknya. Hal ini sesuai dengan teori dengan adanya kepastian dan investasi dari pemerintah dalam menambah modal akan member pengaruh positif terhadap penyaluran kredit. Jika menambah infrastruktur maka akan membentuk lapangan kerja baru bagi masyarakat sehingga keinginan untuk kredit akan meningkat pula.

3. Tingkat Penyaluran Kredit Mempengaruhi Pertumbuhan Ekonomi.

Dengan P-Value yang signifikan dibawah 0,01 persen (*** melambangkan bahwa signifikan dibawah 0,01 persen) maka dengan kepercayaan mendekati 99\% dipercayai bahwa terdapat hubungan langsung antara Tingkat Penyaluran Kredit dan Pertumbuhan Ekonomi. Penyaluran kredit bersifat mempengaruhi pertumbuhan ekonomi. Dimana hubungannya adalah positif yakni sebesar 0,126, sehingga penambahan penyaluran kredit sebesar 1 Triliun akan menaikan pertumbuhan ekonomi sebesar 0,126 persen, berlaku pula untuk sebaliknya.

Setelah menjabarkan hubungan langsung yang ada selanjutnya akan dijabarkan mengenai hubungan tidak langsung yang ada, dimana terlihat bahwa tingkat suku bunga memiliki pengaruh tidak langsung terhadap pertumbuhan ekonomi melalui variabel penyaluran kredit dan belanja modal memiliki pengaruh tidak langsung terhadap pertumbuhan ekonomi melalui jumlah penyaluran kredit. Penjabarannya adalah sebagai berikut:

Tabel 5. Tabel Goodness of Fit Analisis Jalur

\begin{tabular}{cccc}
\hline Varabel Exogen & Variabel Antara & Variabel Endogen & $\begin{array}{c}\text { Pengaruh Tidak } \\
\text { Langsung }\end{array}$ \\
\hline $\begin{array}{c}\text { Tingkat Suku } \\
\text { Bunga }\end{array}$ & Penyaluran Kredit & $\begin{array}{c}\text { Pertumbuhan } \\
\text { Ekonomi }\end{array}$ & $-0,1447$ \\
\hline Belanja Modal & Penyaluran Kredit & $\begin{array}{c}\text { Pertumbuhan } \\
\text { Ekonomi }\end{array}$ & 0,1649 \\
\hline
\end{tabular}

Sumber: Data Diolah, 2016

Hasil ini didapatkan dengan mengkalikan pengaruh langsung yang dimiliki variabel independeen dengan pengaruh langsung variabel antara terhadap variabel dependen. Sehingga pengaruh langsung suku bunga sebesar -1,149 dikalikan dengan 0,126 menghasilkan angka $-0,1447$ begitupula dengan pengaruh belanja modal terhdap pertumbuhan ekonomi melalui variabel penyaluran kredit, yakni 1,309 dikalikan dengan 0,126 menghasilkan 0,1649. 
Dari hasil pengaruh tidak langsung dapat terlihat kedua variabel Exogen memiliki pengaruh tidak langsung yang cukup besar, perbedaanya Tingkat Suku Bunga memiliki hubungan negatif dengan pertumbuhan ekonomi sedangkan Belanja Modal memiliki hubungan positif. Kesimpulan dari hasil analisis jalur ini adalah bahwa tidak ditemukan hubungan langsung antara variabel exogen terhadap endogen (karena tidak signifikan), hal ini menjelaskan bahwa suku bunga dan belanja modal jika ingin mempengaruhi pertumbuhan ekonomi perlu melalui variabel penyaluran kredit sebagai variabel antara.

Di sisi lain, analisis ini tidak menutup kemungkinan akan adanya variabel penghubung lain, akan tetapi, agar sektor riil dapat merasakan dampak kebijakan secara langsung, penyaluran kredit sementara ini merupakan variabel mediasi yang cukup tepat, hal ini dibuktikan secara statistik bahwa variabel ini mampu menjadi mediator antara kebijakan moneter yang diwakili oleh tingkat suku bunga dan kebijaklan fiskal yang diwakili oleh Belanja Modal. Hal ini ditunjukan bahwa dari kedua variabel eksogen memiliki hubungan langsung terhadap Penyaluran Kredit sebagai variabel antara.

Pada penelitian ini tidak ditemukan pengaruh langsung dari tingkat bunga terhadap pertumbuhan ekonomi aataupun belanja modal yang berpengaruh langsung terhadap pertumbuhan ekonomi, sehingga pada penelitian ini tidak didapatkan pengaruh kausal total, dan hanya pengaruh tidak langsung saja. Penelitian ini menegaskan bahwa dalam sinegrasi kebijakan fiskal dan moneter diperlukan variabel penghubung. Dalam kaitannya menyentuh sektor riil maka penyaluran kredit merupakan variabel yang baik yang sudah dibuktikan dari hasil statistik.

\section{Regresi Penyaluran Kredit per Sektor Terhadap Pertumbuhan Ekonomi}

Pada bagian ini dimaksudkan untuk mengetahui penyaluran kredit pada sektor manakah yang mampu memberikan pengaruh terhadap perekonomian Provinsi Jawa Timur. Hal ini dimaksudkan sebagai saran lanjutan dari hasil analisis jalur sebelumnya, dimana pada analisis jalur membuktikan bahwa peningkatan penyaluran kredit mampu menaikkan pertumbuhan ekonomi.

Akan tetapi demi mencapai pembangunan yang efektif dan efisien, maka sumber daya yang ada perlu dikelola sebijak mungkin, sehingga dalam menaikkan penyaluran kredit sebaiknya lebih mengarah pada penyaluran kredit pada sektor yang paling memberikan pengaruh terhadap perekonomian Provinsi Jawa Timur (Nangarumba, 2015).

Kali ini data yang digunakan adalah data pertumbuhan ekonomi sebagai variabel dependen dan lima sektor yang memiliki jumlah penyaluran kredit terbesar, yakni pertanian, industri pengolahan, konstruksi, perdagangan, hotel, dan restoran, dan jasa. Hasilnya akan dijelaskan sebagai berikut setelah tentunya menjelaskan apakah secara statistik telah memenuhi uji asumsi klasik.

\section{Hasil Regresi}

Berdasarkan hasil regresi menggunakan aplikasi eviews 6, didapatkan model estimasi sebagaimana dijabarkan berikut ini adalah hasil regresi menggunakan eviews 6 dan juga disertai dengan penjelasannya. 
Tabel 6. Hasil Regresi

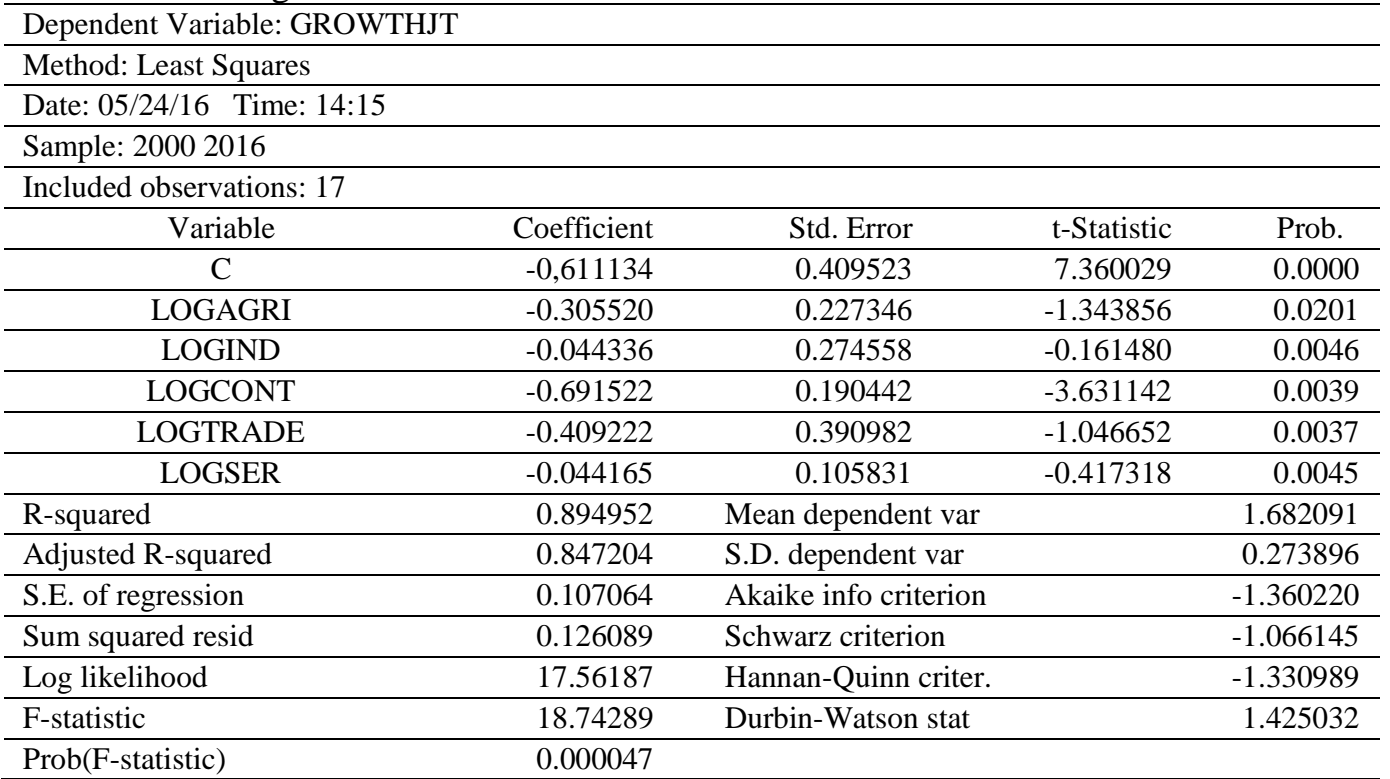

Sumber: Data Diolah, 2016

Dari hasil estimasi pada model Regresi Linier Berganda diatas, maka didapat persamaan sebagai berikut:

GROWTH $=\beta 0+\beta 1$ LN Penyaluran Kredit Sektor Pertanian $+\beta 2$ LN Penyaluran Kredit Sektor Industri $+\beta 3$ LN Penyaluran Kredit Sektor Konstruksi $+\beta 4$ LN Penyaluran Kredit Sektor Perdagangan, Hotel, dan Restoran $+\beta 5$ LN Penyaluran Kredit Sektor Jasa + e

Dimana:

GROWTH $=-0,611134-0,3055201$ it $-0,044336$ X2it $-0,691522$ X3it $0,409222 \times 4$ it $-0,044165 \times 5$ it

Dari model di atas dapat dilihat pengaruh masing-masing variabel independen terhadap variabel dependen (Pertumbuhan Ekonomi) Namun, dikarenakan data tersebut sebelumnya telah ditransformasi dalam bentuk Logaritma Natural (LN), maka dalam intrepetasinya, hasil diatas perlu di inverse atau dengan kata lain anti LN. hasil inverse tersebut adalah sebagaimana dijelaskan dibawah ini.

Tabel 7. Transfromasi Anti Log

\begin{tabular}{ccc}
\hline Variabel & Koefisien & Transformasi Anti LN \\
\hline C & $-0,611134$ & 0,54274 \\
\hline LOGAGRI & $-0,30552$ & 0,73674 \\
\hline LOGIND & $-0,044336$ & 0,95663 \\
\hline LOGCONT & $-0,691522$ & 0,50081 \\
\hline LOGTRADE & $-0,409222$ & 0,66417 \\
\hline LOGSER & $-0,044165$ & 0,95680
\end{tabular}

Sumber: Data Diolah, 2016 
Sehingga model yang dihasilkan adalah sebagai berikut:

$$
\begin{aligned}
\text { GROWTH }= & 0,54274+0,73674_{1 i t}+0,95663 X_{2 i t}+0,50081 X_{3 i t}+0,66417 X_{4 i t}+ \\
& 0,95680 X_{5 i t}
\end{aligned}
$$

Setelah kita mendapatkan model regresi kemudian bagian terpenting adalah proses menjabarkan hasil regresi diatas, tahapan selanjutnya adalah mengintrepetasikan secara satu per satu kemudian kita akan melihat Penyaluran kredit pada sektor manakah yang memberikan pengaruh terbesar bagi pertumbuhan ekonomi Provinsi Jawa Timur.

1. Hasil Konstanta

Konstanta Sebesar 0,54274 menyatakan bahwa jika variabel bebas ( $\mathrm{x}_{1}, \mathrm{x}_{2}, \mathrm{x}_{3}$, $\mathrm{x}_{4}, \mathrm{x}_{5}$ ) dianggap konstan (tidak memberikan pengaruh), maka $\mathrm{Y}$ adalah 0,54274 .

2. Penyaluran Kredit pada Sektor Pertanian

Koefisien Penyaluran Kredit pada Sektor Pertanian memberikan nilai sebesar 0,73674 terhadap pertumbuhan ekonomi. Sehinnga jika terjadi kenaikan terhadap Penyaluran Kredit pada Sektor Pertanian sebesar 1 Triliun maka akan menaikan pertumbuhan ekonomi sebesar 0,73674 persen.

3. Penyaluran Kredit pada Sektor Industri Pengolahan

Koefisien Penyaluran Kredit pada Sektor Industri Pengolahan memberikan nilai sebesar 0,95663 terhadap pertumbuhan ekonomi. Sehinnga jika terjadi kenaikan terhadap Penyaluran Kredit pada Sektor Industri Pengolahan sebesar 1 Triliun maka akan menaikan pertumbuhan ekonomi sebesar 0,95663 persen.

4. Penyaluran Kredit pada Sektor Konstruksi

Koefisien Penyaluran Kredit pada Sektor Konstruksi memberikan nilai sebesar 0,50081 terhadap pertumbuhan ekonomi. Sehinnga jika terjadi kenaikan terhadap Penyaluran Kredit pada Sektor Konstruksi sebesar 1 Triliun maka akan menaikan pertumbuhan ekonomi sebesar 0,50081 persen.

5. Penyaluran Kredit pada Sektor Perdagangan, Hotel, dan Restoran

Koefisien Penyaluran Kredit pada Sektor Perdagangan, Hotel, dan Restoran memberikan nilai sebesar 0,66417 terhadap pertumbuhan ekonomi. Sehinnga jika terjadi kenaikan terhadap Penyaluran Kredit pada Sektor Perdagangan, Hotel, dan Restoran sebesar 1 Triliun maka akan menaikan pertumbuhan ekonomi sebesar 0,66417 persen.

6. Penyaluran Kredit pada Sektor Jasa

Koefisien Penyaluran Kredit pada Sektor Jasa memberikan nilai sebesar 0,95680 terhadap pertumbuhan ekonomi. Sehinnga jika terjadi kenaikan terhadap Penyaluran Kredit pada Sektor Jasa sebesar 1 Triliun maka akan menaikan pertumbuhan ekonomi sebesar 0,95680 persen.

Dari tabel di bawah dapat diketahui bahwa penyaluran kredit pada sektor jasa memiliki pengaruh terbesar dibandingkan keempat sektor lainnya, kemudian diikuti penyaluran kredit pada sektor industri, pertanian, perdagangan, dan kemudian sektor jasa. Pada teori transformasi struktural suatu daerah akan mengalami transformasi dari sektor pertanian, industry pengolahan, kemudian jasa. Dimana kemudian ketiga sektor tersebut harus melakukan sinegrasi berupa kluster industri, agar pembangunan setiap sektor dapat semakin merata, 
hubungannya dengan hasil diatas, adalah bahwa Provinsi Jawa Timur memang memiliki produktifitas yang luar biasa pada sektor industri pengolahannya, yang kemudian diikuti perdagangan, hotel, dan restoran, dan kemudian sektor pertanian dan selanjutnya terdapat sektor jasa.

Tabel 7. Urutan Penyaluran Kredit per Sektor

\begin{tabular}{cc}
\hline Sektor & Koefisien \\
\hline PK Jasa & 0,956796073 \\
\hline PK Industri & 0,956632475 \\
\hline PK Pertanian & 0,73674017 \\
\hline PK Perdagngan & 0,664166771 \\
\hline PK Konstruksi & 0,500813251
\end{tabular}

Sumber: Data Diolah, 2016

Namun, berdasar teori tersebut, mengandung arti dimana bahwa semakin majunya teknologi maka akan mendorong masyarakat untuk berproduksi di sektor jasa. Selain itu sektor jasa juga memiliki barrier penyerapan tenaga kerja yang rendah, bahwasannya jika tenaga kerja memiliki keahlian khusus pada bidang tertentu akan memudahkan mereka untuk terserap di sektor jasa. Berbeda dengan sektor Industri Pengolahan, dimana hambatannya lebih banyak terletak pada barier berupa kualifikasi pendidikan. Sehingga berdasarkan pertimbangan tersebut, salah satu keluaran pada penelitian ini adalah mendorong penyaluran kredit pada sektor jasa.

\section{KESIMPULAN}

Berdasarkan analisis yang telah dilakukan, maka dapat ditarik tiga kesimpulan, kesimpulan pertama bahwa kebijakan moneter merupakan kewenangan Bank Sentral (BI). Dalam upaya pengingkatan perekonomian nasional, BI menjalankan instrument moneter, berupa tingkat suku. Tingkat suku bunga oleh BI terus diturunkan sehingga diharapkan akan berdampak peningkatan perekonomian karena dengan suku bunga yang terus turun akan meningkatkan penyaluran dana untuk sektor riil. Kesimpulan kedua, dalam kajian ini, kebijakan Fiskal untuk dapat merespon Kebijakan Moneter dari pusat memerlukan variabel antara yang menjadi penghubung antara kedua kebijakan tersebut. Dalam hal ini kebijakan moneter diwakili oleh tingkat bunga dan kebijakan fiskal diwakili belanja modal. Dalam kajian ini, diyakini variabel penghubung tersebut adalah penyaluran kredit. Hasil analisis menunjukkan bahwa penyaluran kredit dapat mempengaruhi pertumbuhan ekonomi sebagai variabel antara. Selanjutnya kesimpulan terakhir, berdasarkan hasil Regresi, penyaluran kredit pada sektor jasa memiliki pengaruh terbesar diikuti penyaluran kredit pada Sektor Industri, Sektor Pertanian, Sektor Perdagangan, dan Sektor Konstruksi.

Berdasarkan hasil analisis yang telah diuraikan, maka dapat diberikan beberap rekomendasi kebijakan yang dapat dilakukan oleh Pemerintah Provinsi Jawa Timur: Pemerintah daerah harus mempersipakan sektor-sektor ekonomi yang mampu mendorong peningkatan penyerapan kredit. Hasil analisis menunjukkan bahwa peningkatan penyaluran kredit akan dapat meningkatkan pertumbuhan ekonomi. Salah satu sektor ekonomi yang dapat didorong untuk penyerapan kredit adalah sektor UMKM. UMKM harus dibina agar mampu memiliki status 
bankable, minimal fisibel. Program-program pelatihan dan pendampingan pada UMKM dapat terus ditingkatkan karena potensi besar yang dimiiliki oleh UMKM Jawa Timur yang mencapai lebih dari 6,8 juta unit. Dalam upaya meningkatkatkan penyaluran kredit, sektor-sektor ekonomi harus dikembangkan. Terutamanya sektor Jasa, Sektor Industri, Sektor Pertanian, Sektor Perdagangan, dan Sektor Konstruksi. Perencanaan dan penganggaran yang lebih baik. Alokasi belanja modal yang harus terus meningkat, efisiensi belanja akan menjadi stimulus dalam perekonomian daerah. selain itu, akan semakin meminimalisasi SiLPA.

\section{DAFTAR RUJUKAN}

Alatan, T. S. D., \& Basana, S.R. (2015). Pengaruh Pemberian Kredit Terhadap Ekonomi Regional Jawa Timur. Finesta, 3(1), 63-67.

Badan Pusat Satistik (2016). Badan Pusat Statistik Jawa Timur, edisi berbagai tahun dan online. www.jatim.bps.go.id.

Baltagi, B. H. (2001). Econometric analysis of panel data. (2nd Edition). West Sussex: John Wiley \& Sons, LTD.

Bank Indonesia. (2016). Kajian Ekonomi Regional Tw IV 2015 Jawa Timur. Kantor Bank Indonesia perwakilan Surabaya.

Direktorat Jenderal Perimbangan Keuangan daerah. (2016). Statistik Keuangan Daerah. diunduh Maret 2016.

Donmoyer, R. (2008). Paragidm. In L. M. Given (Ed), Sage Encyclopedia of Quantitative Research Methods (Vol 2, PP 591-195). Thousand Oaks, CA: Sage.

Fatas, A., \& Mihov, I. (2012). Fiscal Policy as Stabilization Tool. The B.E. Journal of Macroeconomics, 12(3), 1-66.

Ghozali, I. \& Fuad. 2008. Structural Equation Modeling. Semarang: Universitas Diponegoro.

Goeltom, M. S. (2012). Koordinasi dan Interaksi Kebijakan Fiskal-Moneter: Tantangan ke Depan (Koordinasi Kebijakan Moneter Dan Fiskal: Tantangan Dan Strategi Pemeliharaan Stabilitas Makro Dan Pertumbuhan Ekonomi Untuk Mewujudkan Kesejahteraan Rakyat). Yogyakarta: Penerbit Kanisius.

Idayanti, E. (2005). Pengaruh Kebijakan Moneter Terhadap Pertumbuhan Ekonomi Pasca Krisis di Indonesia. Diakses dari https://digilib.uns.ac.id

Kuncoro, M. (2004). Otonomi \& Pembangunan Daerah: Reformasi, Perencanaan, Strategi, dan Peluang. Penerbit Erlangga, Jakarta.

Mahdi., A, H., \& Syofyan, E. (2013). Pengaruh Kebijakan Fiskal Dan Moneter Terhadap Pertumbuhan Ekonomi Provinsi Jambi. Jurnal Kajian Ekonomi, 2(4), 1-9.

Mankiw, N. G. (2006). Pengantar Ekonomi Makro. Jakarta: Ghalia Indonesia.

Muzakky, A., Suhadak., \& Topowijoyo. (2015). Pengaruh Inflasi, Tingkat Suku Bunga SBI, Pendapatan Per Kapita, Dan Ekspor Terhadap Nilai Tukar Rupiah Dan Pertumbuhan Ekonomi (Studi Pada Bank Indonesia Periode Tahun 2002-2013). Jurnal Administrasi Bisnis, 23(1), 1-9.

Nanga, M. (2005). Makroekonomi: Teori, Masalah dan Kebijakan, PT Raja, Jakarta: Grafindo Perkasa. 
Nangarumba, M. (2015). Analisis Pengaruh Struktur Ekonomi, Upah Minimum Provinsi, Belanja Modal, dan Investasi terhadap Ketimpangan Pendapatan di Seluruh Provinsi di Indonesia Tahun 2005-2014. Jurnal Ekonomi dan Studi Pembangunan, 7(2), 9-26.

Nopirin. (1992). Ekonomi Moneter Buku 2. Yogyakarta: BPFE

Rosya, N., Amar, S., \& Syofyan, E. (2013). Analisis Permintaan Agregat dan Penawaran Agregat di Sumatera Barat. Jurnal Kajian Ekonomi, 2(3), 6684.

Santoso, S. (2015). Menguasai Statistik Parametrik Konsep dan Aplikasi dengan SPSS. Jakarta: PT Elex Media Komputindo. 